\title{
Sorafenib for the treatment of solid malignancies: what about the cancer microenvironment?
}

\author{
This article was published in the following Dove Press journal: \\ International Journal of Nanomedicine \\ 22 October 2013 \\ Number of times this article has been viewed
}

\section{Ciprian Tomuleasa \\ Andrei Cucuianu \\ Mihaela Aldea \\ loana Berindan-Neagoe}

Research Center of Functional Genomics and Translational Medicine, Iuliu Hatieganu University of Medicine and Pharmacy, Cluj Napoca, Romania

Correspondence: Ciprian Tomuleasa luliu Hatieganu University of Medicine and Pharmacy, Bulevardul 2I Decembrie $\mathrm{Nr} 73,400$ I24, Cluj Napoca, Romania Email ciprian.tomuleasa@umfcluj.ro

\section{Dear editor}

We have read with great interest the study of Kim et al, recently published in the International Journal of Nanomedicine. ${ }^{1}$ The physicians from South Korea describe the anti-tumor efficacy of sorafenib in cholangiocarcinoma, a malignancy with a dismal prognosis and refractory to most chemotherapy options. Surgery is the only curative option, but is limited to only a small number of cases due to the late diagnosis. ${ }^{2}$ This emphasizes the need to develop new approaches for such cases and the first potential new option is the tyrosine kinase inhibitor sorafenib, already proven to improve the therapeutic ratio of hepatocellular carcinoma, as according to Llovet et al. ${ }^{3}$ But unlike hepatocellular carcinoma, cholangiocarcinomas are epithelial cancers with a highly developed desmoplastic stroma due to the interaction between the cancer cell and the cancer associated fibroblasts (CAFs), as well as the macrophages, and the natural killer (NK) cells. ${ }^{4}$ This tumor microenvironment makes it difficult for a chemotherapy drug to reach the cancer cell and be efficient, which partially explains the reason why Kim et $\mathrm{al}^{1}$ developed a sorafenib-coated stent, that can be placed inside the biliary tree and deliver the drug continuously.

Sorafenib inhibits both the cancer cell proliferation and its neo-angiogenesis by inhibiting the receptor for tyrosine kinases and thus acting on the signaling pathways via vascular endothelial growth factor receptor (VEGFR)-2 and -3, platelet-derived growth factor receptor (PDGFR)- $\beta$, and mast/stem cell growth factor receptor. One of the first trials confirmed its efficacy in advanced, metastasized renal cell carcinoma, but only after immunotherapy with interleukin (IL)-2 and interferon (IFN)-alpha. ${ }^{5}$ This highlights the need for a combined therapy, that uses immunotherapy together with tyrosine kinase inhibitors to target not only the cancer cell, but also the cancer microenvironment. This is of very special importance, as these drugs may indeed affect the malignant cell, but they also disrupt the local cancer niche, as proven by the very recent paper of Zhang et al. ${ }^{6}$ The group stated that sorafenib may actually kill some of the cancer cells, but it also promotes the dissemination of the cancer due to its "off target" effects on the niche, especially on the NK cells. IL-2 activated NK cells will enhance the production of IFN-gamma and tumor necrosis factor (TNF)-alpha, ${ }^{7}$ resulting in a boosted innate immune response against the cancer. In their excellent study, Zhang et $\mathrm{al}^{6}$ have proven that sorafenib directly affects the proliferation and function of NK cells by inhibiting the extracellular signal-regulated kinases (ERK) pathway. Even if this drug did not significantly change the number of $\mathrm{CD} 4+/ \mathrm{CD} 8+\mathrm{T}$ lymphocytes, it affected both the 
initial cancer niche, as well as the pre-metastatic niche and thus it indirectly promoted the metastasis of the cancer cell to distant organs, such as the lungs.

We have no reason to doubt the results of Kim et $\mathrm{al}^{1}$ and are confident that the data provided by these colleagues are of high importance for the management of patients diagnosed with cholangiocarcinoma and are in accordance with international data. However, these studies were done using HuCC-T1 cells, a line of differentiated cancer cells. In our experience, we have proven that a liver malignancy also includes a small, sub-population of stem-like cells (CSC), responsible for resistance to chemotherapy, increased angiogenesis and finally, the clinical relapse of the patient. ${ }^{8}$ Sorafenib is no exception to this rule, as already proven by our research ${ }^{9,10}$ and not only affects the malignancy, but indirectly by helping promotion and dissemination, as CSCs have a higher potential for distant metastasis.

A more holistic vision of cancer and its biology would take into consideration not only the actual cancer cell, but also its dynamics, as well as the interaction with the surrounding microenvironment. The solution might be the use of adjuvant immunotherapy along with new, targeted molecular therapy drugs for patients with unresectable disease in order to obtain long-term clinical remissions.

\section{Disclosure}

The authors report no conflicts of interest in this work.

\section{References}

1. Kim do H, Jeong YI, Chung CW, et al. Preclinical evaluation of sorafenib-eluting stent for suppression of human cholangiocarcinoma cells. Int J Nanomedicine. 2013;8:1697-1711.

2. Nathan H, Pawlik TM, Wolfgang CL, Choti MA, Cameron JL, Schulick RD. Trends in survival after surgery for cholangiocarcinoma: a 30-year population-based SEER database analysis. J Gastrointest Surg. 2007;11(11):1488-1496.

3. Llovet JM, Ricci S, Mazzaferro V, et al. Sorafenib in advanced hepatocellular carcinoma. N Engl J Med. 2008;359(4):378-390.

4. Mertens JC, Fingas CD, Christensen JD, et al. Therapeutic effects of deleting cancer-associated fibroblasts in cholangiocarcinoma. Cancer Res. 2013;73(2):897-907.

5. Escudier B, Lassau N, Angevin E, et al. Phase I trial of sorafenib in combination with IFN alpha-2a in patients with unresectable and/or metastatic renal cell carcinoma or malignant melanoma. Clin Cancer Res. 2007;13(6):1801-1809.

6. Zhang QB, Sun HC, Zhang KZ, et al. Suppression of natural killer cells by sorafenib contributes to prometastatic effects in hepatocellular carcinoma. PLoS One. 2013;8(2):e55945.

7. Moretta L, Bottino C, Pende D, Castriconi R, Mingari MC, Moretta A. Surface NK receptors and their ligands on tumor cells. Semin Immunol. 2006;18(3):151-158.

8. Tomuleasa C, Soritau O, Rus-Ciuca D, et al. Isolation and characterization of hepatic cancer cells with stem-like properties from hepatocellular carcinoma. J Gastrointestin Liver Dis. 2010;19(1):61-67.

9. Tomuleasa C, Soritau O, Fischer-Fodor E, et al. Arsenic trioxide plus cisplatin/interferon $\alpha-2 b /$ doxorubicin/capecitabine combination chemotherapy for unresectable hepatocellular carcinoma. Hematol Oncol Stem Cell Ther. 2011;4(2):60-66.

10. Tomuleasa C, Cristea V, Irimie A. Sorafenib for advanced-stage hepatocellular carcinoma. Eur J Gastroenterol Hepatol. 2012;24(3): 346-347.
International Journal of Nanomedicine

\section{Publish your work in this journal}

The International Journal of Nanomedicine is an international, peerreviewed journal focusing on the application of nanotechnology in diagnostics, therapeutics, and drug delivery systems throughout the biomedical field. This journal is indexed on PubMed Central, MedLine, CAS, SciSearch ${ }^{\circledR}$, Current Contents ${ }^{\circledR} /$ Clinical Medicine,

\section{Dovepress}

Journal Citation Reports/Science Edition, EMBase, Scopus and the Elsevier Bibliographic databases. The manuscript management system is completely online and includes a very quick and fair peer-review system, which is all easy to use. Visit http://www.dovepress.com/ testimonials.php to read real quotes from published authors. 